\title{
Faktor-Faktor yang Memengaruhi Kepemilikan Jaminan Kesehatan Pekerja Sektor Informal di Indonesia
}

\author{
Determinants of Health Insurance Ownership in The Informal Sector Workers in \\ Indonesia
}

\section{Dodi Satriawan ${ }^{1}$, Agus Joko Pitoyo², Sri Rum Giyarsih}

Diterima: 7 Juli 2020

Disetujui: 31 Agustus 2020

\begin{abstract}
Abstrak: Investasi kesehatan memiliki peranan penting dalam pembangunan ekonomi dan modal utama agar dapat melakukan pekerjaan. Ketiadaan jaminan kesehatan dapat menjadi sebuah jebakan kemiskinan. Hal inilah yang menjadi alasan mendasar mengapa jaminan kesehatan mendapat perhatian besar dalam SDG's. Berdasarkan data SAKERNAS tahun 2017 persentase pekerja sektor informal di Indonesia masih cukup tinggi yaitu mencapai 57,03 persen dan dari jumlah tersebut baru sebanyak 57,3 persen pekerja sektor informal yang memiliki jaminan kesehatan yang artinya hampir separuh dari pekerja sektor informal bekerja tanpa perlindungan jaminan kesehatan. Penelitian ini bertujuan untuk mengetahui faktor-faktor yang memengaruhi kepemilikan jaminan kesehatan pekerja sektor informal di Indonesia. Analisis dilakukan secara inferensial menggunakan chi-square dan regresi logistik biner menggunakan data SUSENAS Maret 2018. Berdasarkan hasil analisis menggunakan chi-square didapatkan hasil bahwa semua variabel bebas memiliki hubungan yang bermakna dengan kepemilikan jaminan kesehatan sehingga analisis dilanjutkan dengan regresi logistik. Dari hasil olah regresi logistik didapatkan faktor-faktor yang memengaruhi kepemilikan jaminan kesehatan pekerja sektor informal di Indonesia adalah wilayah tempat tinggal, status perkawinan, status dalam rumah tangga, jenis kelamin, umur, kepemilikan NIK, tingkat pendidikan, lapangan usaha, keluhan kesehatan, status ekonomi, dan pengobatan sendiri.
\end{abstract}

\section{Kata kunci: sektor informal, jaminan kesehatan, cakupan kesehatan universal}

\begin{abstract}
Health investment has an important role in economic development and major capital in order to be able to do work. Lack of health insurance can be a poverty trap. This is the fundamental reason why health insurance receives the most attention in the SDG's. Based on SAKERNAS data in 2017 the percentage of informal sector workers in Indonesia is still quite high, reaching 57.03 percent and of that number only 57.3 percent of informal sector workers have health insurance which means that almost half of the informal sector workers work without health insurance protection . This study aims to determine the factors that influence the ownership of health insurance for informal sector workers in Indonesia. The analysis was conducted inferentially using chi-square and binary logistic regression using SUSENAS data in March 2018. Based on the results of the analysis using chi-square obtained the results that all independent variables have a meaningful relationship with health insurance ownership so the analysis is continued with logistic regression. From the results of logistic regression it is found that the factors that influence the health insurance ownership of informal sector workers in Indonesia are the area of residence, marital status, status in the household, gender, age, NIK ownership, education level, business field, health complaints, status economics, and self-medication.
\end{abstract}

Keywords: informal sector, health insurance, universal health coverage

\footnotetext{
${ }^{1}$ Badan Pusat Statistik (BPS) Kabupaten Padang Lawas Utara

${ }^{2}$ Universitas Gadjah Mada
}

Korespondensi: dodisatriawan@bps.go.id 


\section{PENDAHULUAN}

Investasi kesehatan dan pembangunan ekonomi memiliki kaitan yang sangat erat. Pada level makro, penduduk yang memiliki derajat kesehatan yang baik merupakan input penting dalam penurunan angka kemiskinan serta pembangunan ekonomi dalam jangka panjang. Pada level mikro, kesehatan menjadi dasar bagi produktivitas kerja individu atau rumah tangga. Tenaga kerja yang sehat secara fisik maupun mental akan lebih kuat, lebih produktif, serta lebih mampu dalam memperoleh penghasilan yang tinggi (Atmawikarta, 2002). Suharto (2009) dalam tulisannya mengemukakan, dalam keseharian banyak keluarga terjebak hutang demi membayar biaya kesehatan salah satu anggota keluarganya. Satu anggota keluarga yang sakit tersebut dapat mempersuram masa depan seluruh anggota keluarganya. Ketiadaan jaminan kesehatan dapat menjadi sebuah jebakan kemiskinan. Inilah yang menjadi alasan mendasar mengapa jaminan kesehatan mendapat perhatian besar dalam Sustainable Development Goals (SDG's).

SDG's telah menetapkan beberapa target yang harus dicapai setiap negara. Salah satu target tersebut adalah memastikan cakupan kesehatan yang berkualitas bagi setiap orang, atau kemudian disebut dengan Cakupan Kesehatan Universal (Universal Health Coverage/UHC). UHC merupakan suatu sistem pembiayaan kesehatan yang menjamin setiap penduduk memiliki akses secara adil dan merata terhadap pelayanan kesehatan yang dibutuhkan, berkualitas, dan terjangkau secara finansial, baik pelayanan promotif, kuratif, preventif, maupun rehabilitatif (WHO, 2015). Terdapat pengaruh positif antara pelaksanaan UHC terhadap perekonomian, dimana penerapan UHC yang baik mampu berdampak pada peningkatan pertumbuhan tenaga kerja, pertumbuhan gaji, serta produktivitas tenaga kerja (Ahoobim dkk, 2012). Pada saat ini UHC sebagai bagian dari reformasi sistem kesehatan telah dilaksanakan oleh hampir setengah negara di dunia dengan berbagai tingkatan pendapatan (Boerma dkk, 2014). Brazil, Rusia, India, China dan Afrika Selatan merupakan negara yang secara total jumlah penduduknya mewakili hampir setengah populasi di dunia telah berkomitmen dalam menerapkan sistem UHC ini (Marten dkk, 2014).

Pada tahun 2014, pemerintah Indonesia menerapkan sistem Jaminan Kesehatan Nasional (JKN) bagi setiap penduduknya. Sistem ini diberlakukan secara bertahap dan ditargetkan pada tahun 2019 dapat mencakup seluruh penduduk Indonesia (BPJS Kesehatan, 2017). Berdasarkan data BPJS Kesehatan tahun 2019 jika dilihat berdasarkan aspek cakupan kepesertaan sejak awal penerapan sistem JKN yakni tahun 2014 sampai periode 2019, perkembangan jumlah peserta jaminan kesehatan menunjukkan peningkatan yang signifikan.cakupan kepesertaan jaminan kesehatan di Indonesia terus mengalami peningkatan. Jumlah peserta jaminan kesehatan pada tahun 2014 masih berkisar sebanyak 133,4 juta jiwa atau sekitar 49,3 persen dan per tanggal 31 Oktober 2019 meningkat menjadi 222,2 juta jiwa atau lebih dari 83,8 persen dari total penduduk Indonesia, namun jika dilihat berdasarkan target yang dicanangkan pemerintah tahun 2019 yaitu pencapaian UHC dengan cakupan kepesertaan minimal 95 persen atau 257,5 juta jiwa dari total penduduk Indonesia maka capaian kepesertaan jaminan kesehatan yang ada saat ini belum maksimal (Kemenkes, 2019).

Jika membahas mengenai produktivitas tenaga kerja yang tinggi maka hal ini tidak bisa terlepas dari sektor informal. Pitoyo (2007) menyatakan bahwa sektor ini sangat produktif dan berkontribusi dalam penciptaan lapangan kerja untuk pengentasan kemiskinan. Sektor informal yang selama ini dipandang sebelah mata justru menjadi perwujudan dari perjuangan rakyat dalam menentukan nasibnya dan mempertahankan hidup sehingga sudah seharusnya sektor ini mendapatkan perhatian lebih. Peranan sektor informal menjadi penting dalam hal penyerapan tenaga kerja. Data BPS yang bersumber dari Survei Angkatan Kerja Nasional (SAKERNAS) tahun 2017 menunjukkan bahwa persentase pekerja sektor informal di Indonesia masih cukup tinggi yaitu mencapai 57,03 persen dari 
total penduduk yang bekerja secara nasional. Namun, dari jumlah tersebut baru sebanyak 57,3 persen pekerja sektor informal yang memiliki jaminan kesehatan yang artinya hampir separuh dari pekerja sektor informal bekerja tanpa perlindungan jaminan kesehatan. Hal ini perlu menjadi perhatian serius bagi pemerintah karena ketiadaan jaminan kesehatan akan berpengaruh terhadap utilisasi pelayanan kesehatan, pengeluaran kesehatan dan status kesehatan (Thabrany, 2011).

Idris (2016) dalam penelitiannya menyatakan bahwa ketiadaan jaminan kesehatan di kalangan pekerja sektor informal akan mengakibatkan pengeluaran katastropik yang mengancam mereka jatuh miskin. Medyati dkk (2018) juga menyatakan jika berbagai penyakit yang bersumber dari lingkungan kerja seperti faktor kebisingan, stres akibat kerja, maupun disebabkan oleh karena gaya hidup yang tidak sehat dapat menyerang siapapun terutama para pekerja sektor informal. Departemen Kesehatan (2008) dalam laporannya memaparkan bahwa terdapat beberapa hal yang memperparah kondisi pekerja sektor informal diantaranya tempat tinggal yang kumuh, pendapatan yang rendah dan tidak menentu, serta lingkungan kerja yang tidak sehat dan bahkan membahayakan, membuat pekerja sektor informal hidup penuh resiko dan senantiasa berada dalam ancaman seperti kecelakaan kerja, penyakit bahkan kematian.

Berbagai fakta di atas menunjukkan bahwa kepemilikan jaminan kesehatan merupakan hal yang penting bagi pekerja sektor informal dan seharusnya menjadi alasan bagi pemerintah untuk memberikan perlindungan mengingat besarnya jumlah pekerja informal dan kontribusi nyatanya dalam pembangunan (ILO, 2013). Perlindungan terhadap pekerja informal bukan hanya bicara soal upah yang layak, akan tetapi juga mengenai akses ke berbagai fasilitas dan tersedianya jaminan sosial terutama bidang kesehatan. Dari argumen-argumen di atas, maka penelitian ini bertujuan untuk mengetahui faktor-faktor yang memengaruhi kepemilikan jaminan kesehatan pekerja sektor informal di Indonesia. Penelitian ini dapat digunakan sebagai dasar informasi dalam menetapkan strategi atau kebijakan untuk pelaksanaan pembangunan kesehatan, serta dapat dijadikan landasan untuk memahami isu-isu perlindungan sosial, khususnya jaminan sosial bidang kesehatan bagi pekerja sektor informal. Selain itu penelitian ini diharapkan dapat dijadikan bahan masukan atau suatu informasi untuk penelitian-penelitian selanjutnya terkait kepemilikan jaminan kesehatan pekerja. Dengan mengetahui faktor-faktor yang memengaruhi kepemilikan jaminan kesehatan pekerja sektor informal, pemerintah dapat menentukan potensi dan permasalahan yang bisa distimulasi untuk mendorong peningkatan kepemilikan jaminan kesehatan para pekerja tersebut, sehingga penelitian ini sekaligus dapat membantu pemerintah untuk lebih selektif dan efektif dalam menentukan kebijakan terhadap pekerja sektor informal maupun sebagai bahan masukan untuk perencanaan bagi pemerintah Indonesia maupun pihak-pihak yang terkait penentuan kebijakan kesehatan bagi sektor informal di era JKN.

\section{METODE}

Penelitian ini memanfaatkan data sekunder Badan Pusat Statistik dari Survei Sosial Ekonomi Nasional (SUSENAS) Indonesia yang dilakukan pada bulan Maret tahun 2018. Data yang digunakan dalam penelitian ini menggunakan level individu sebagai unit analisis penelitian. Untuk menjawab tujuan penelitian ini digunakan uji independensi (chi-square) dan regresi logistik biner. Uji independensi (asosiasi) merupakan analisis bivariat yang digunakan untuk melihat keterkaitan/hubungan antar variabel bebas dengan variabel terikat menggunakan uji chi-square. Setelah dilakukan pengujian dengan chi-square dan didapatkan variabel-variabel bebas yang dinyatakan terdapat hubungan dengan kepemilikan jaminan kesehatan pekerja sektor informal maka variabel-variabel tersebut nantinya akan diolah lebih lanjut dengan menggunakan analisis regresi logistik untuk menentukan variabel-variabel 
bebas apa saja yang signifikan dan memiliki pengaruh terhadap variabel kepemilikan jaminan kesehatan pekerja sektor informal.

\section{HASIL DAN PEMBAHASAN}

Pembahasan pada sub bab ini meliputi analisis bivariat mengenai hubungan antara kepemilikan jaminan kesehatan dengan faktor sosial ekonomi rumah tangga faktor sosial demografi individu serta analisis regresi logistik untuk mengetahui faktor-faktor yang memengaruhi kepemilikan jaminan kesehatan pekerja sektor informal.

Hubungan antara masing-masing variabel bebas dengan variabel kepemilikan jaminan kesehatan ditunjukkan oleh tabel 1 di bawah ini. Hasil analisis bivariat dengan menggunakan chi-square dapat menunjukkan bahwa masing-masing variabel bebas memiliki hubungan ataupun tidak memiliki hubungan yang bermakna dengan kepemilikan jaminan kesehatan. Adanya hubungan tersebut ditunjukkan dengan nilai signifikansi kurang dari atau sama dengan 0,05. Nantinya variabel yang memiliki hubungan saja yang akan diolah lebih lanjut menggunakan analisis regresi logistik biner.

Tabel 1. Hasil Uji Chi-square Masing-masing Variabel Bebas Terhadap Kepemilikan Jaminan Kesehatan Pekerja Sektor Informal di Indonesia Tahun 2018

\begin{tabular}{lrr}
\hline \multicolumn{1}{c}{ Variabel } & Nilai Pearson & Sig. \\
\multicolumn{1}{c}{$(1)$} & $\chi^{2}$ & $(3)$ \\
\hline Wilayah Tempat Tinggal & $(2)$ & 0.000 \\
Status Perkawinan & 49.847 & 0.000 \\
Status Dalam Rumah Tangga & 28.325 & 0.000 \\
Jenis Kelamin & 768.473 & 0.000 \\
Umur & 236.982 & 0.000 \\
Kepemilikan NIK & 359.978 & 0.000 \\
Tingkat Pendidikan & 25.543 & 0.000 \\
Lapangan Usaha & 799.536 & 0.000 \\
Keluhan Kesehatan & 164.166 & 0.000 \\
Status Ekonomi & 332.574 & 0.000 \\
Pengobatan Sendiri & 236.983 & 0.040 \\
\hline
\end{tabular}

Sumber: SUSENAS KOR 2018, Diolah.

Pada tabel 1 di atas didapatkan nilai signifikansi dari masing-masing variabel wilayah tempat tinggal, status perkawinan, status dalam rumah tangga, jenis kelamin, umur, kepemilikan NIK, tingkat pendidikan, lapangan usaha, keluhan kesehatan, status ekonomi, dan pengobatan sendiri lebih kecil dari 0,05 yang berarti bahwa terdapat hubungan antara masing-masing variabel bebas dengan kepemilikan jaminan kesehatan. Selanjutnya untuk menjelaskan seberapa besar kecenderungan/pengaruh masing-masing variabel bebas terhadap kepemilikan jaminan kesehatan pekerja sektor informal digunakan odds ratio.

\section{Uji Signifikansi Model (Overall Test)}

Model regresi logistik yang akan diuji adalah sebagai berikut:

$$
\hat{\pi}(\mathrm{D})=\frac{\exp \left(\beta_{0}+\beta_{1} \mathrm{D}_{1}+\beta_{21} \mathrm{D}_{21}+\beta_{22} \mathrm{D}_{22}+\beta_{31} \mathrm{D}_{31}+\beta_{32} \mathrm{D}_{32}+\beta_{33} \mathrm{D}_{33}\right.}{1+\exp \left(\beta_{0}+\beta_{1} \mathrm{D}_{1}+\beta_{21} \mathrm{D}_{21}+\beta_{22} \mathrm{D}_{22}+\beta_{31} \mathrm{D}_{31}+\beta_{32} \mathrm{D}_{32}+\beta_{33} \mathrm{D}_{33}\right.}
$$




$$
\begin{aligned}
& \frac{+\beta_{4} D_{4}+\beta_{51} D_{51}+\beta_{52} D_{52}+\beta_{6} D_{6}+\beta_{71} D_{71}+\beta_{72} D_{72}+\beta_{81} D_{81}}{+\beta_{4} D_{4}+\beta_{51} D_{51}+\beta_{52} D_{52}+\beta_{6} D_{6}+\beta_{71} D_{71}+\beta_{72} D_{72}+\beta_{81} D_{81}} \\
& \frac{+\beta_{82} D_{82}+\beta_{9} D_{9}+\beta_{101} D_{101}+\beta_{102} D_{102}+\beta_{11} D_{11}}{+\beta_{82} D_{82}+\beta_{9} D_{9}+\beta_{101} D_{101}+\beta_{102} D_{102}+\beta_{11} D_{11}}
\end{aligned}
$$

Hasil penghitungan statistik uji G yaitu sebesar 3315,664 dengan p-value sebesar 0,000 . Selanjutnya hasil penghitungan nilai statistik uji $G$ tersebut dibandingkan dengan nilai $\chi_{\text {tabel }}^{2}$ dimana $\chi_{(18 ; 0,05)}^{2}$ sebesar 28,869. Karena nilai statistik uji G lebih besar daripada nilai $\chi_{(18 ; 0,05)}^{2}$, maka dapat diambil keputusan untuk menolak Ho. Selain itu dapat juga dilihat dari nilai $p$-value yaitu sebesar 0,000 yang jauh lebih kecil dari $\alpha=0,05$. Dengan keputusan menolak Ho maka dapat diambil kesimpulan bahwa minimal ada satu variabel bebas yang berpengaruh terhadap variabel kepemilikan jaminan kesehatan pekerja sektor informal. Oleh karena itu, pengujian dapat dilanjutkan secara parsial untuk mengetahui variabel mana saja yang berpengaruh signifikan sehingga dapat dimasukkan ke dalam model.

Pengujian signifikansi model dilihat dari tabel Hosmer and Lemeshow Test. Hasil uji Hosmer and Lemeshow dilihat pada kolom chi-square hitung sebesar 10,418 dibandingkan nilai $\chi_{\text {tabel }}^{2}$ dimana $\chi_{(8 ; 0,05)}^{2}$ sebesar 15,507 . Ternyata nilai chi-square hitung lebih kecil daripada $\chi_{(8 ; 0,05)}^{2}$ atau dengan melihat nilai signifikansinya sebesar 0,220 yang lebih besar dari $\alpha=0,05$. Maka dapat diambil keputusan untuk menerima Ho, sehingga dapat dikatakan bahwa model yang terbentuk telah cukup untuk menjelaskan data empiris.

\section{Uji Signifikansi Parameter Model secara Individu (Uji Parsial)}

Uji ini digunakan untuk melihat keberartian masing-masing variabel bebas dalam model secara parsial. Uji Wald pada output SPSS Version 21 dilihat dari tabel Variables in the Equation. Hasilnya diketahui bahwa variabel penjelas yang berpengaruh secara signifikan terhadap kepemilikan jaminan kesehatan pekerja sektor informal adalah wilayah tempat tinggal, status perkawinan, status dalam rumah tangga, jenis kelamin, umur, kepemilikan NIK, tingkat pendidikan, lapangan usaha, keluhan kesehatan, status ekonomi, dan pengobatan sendiri. Khusus untuk variabel lapangan usaha kategori industri tidak berpengaruh secara signifikan terhadap kepemilikan jaminan kesehatan pekerja sektor informal. Variabel yang signifikan berpengaruh terhadap kepemilikan jaminan kesehatan pekerja sektor informal dapat dilihat dari kolom signifikansi yang menunjukkan angka yang lebih kecil dari $\alpha=0,05$. Selain itu dapat juga dilihat dari nilai Wald yang dibandingkan dengan $\chi_{(1 ; 0,05)}^{2}=3,841$. Jika nilai Wald variabel penjelas lebih besar dari nilai $\chi_{(1 ; 0,05)}^{2}$, maka dapat disimpulkan bahwa variabel penjelas tersebut signifikan sehingga dapat dimasukkan ke dalam persamaan regresi logistik. Hasil pengujian parameter secara singkat dapat dilihat pada tabel 2 di bawah ini:

Tabel 2 Nilai Penduga Parameter, Statistik Uji Wald, dan Odds Ratio dari Masing-masing Variabel Bebas dan Konstanta

\begin{tabular}{llcccc}
\hline \multicolumn{1}{c}{ Variabel } & B & Wald & f & Sig. & Exp(B) \\
\multicolumn{1}{c}{$(1)$} & \multicolumn{1}{c}{$(2)$} & \multicolumn{1}{c}{$(3)$} & \multicolumn{1}{c}{$(4)$} & \multicolumn{1}{c}{$(5)$} & \multicolumn{1}{c}{$(6)$} \\
\hline Wilayah Tempat Tinggal & 0.640 & 130.843 & 1 & 0.000 & 1.897 \\
Status Perkawinan & & 122.272 & 2 & 0.000 & \\
Status Perkawinan (1) & 0.208 & 102.263 & 1 & 0.000 & 1.231 \\
Status Perkawinan (2) & 0.036 & 5.640 & 1 & 0.018 & 1.037 \\
Status Dalam Rumah Tangga & & 727.937 & 3 & 0.000 & \\
\hline
\end{tabular}




\begin{tabular}{|c|c|c|c|c|c|}
\hline $\begin{array}{c}\text { Variabel } \\
(1)\end{array}$ & $\begin{array}{l}\text { B } \\
(2) \\
\end{array}$ & $\begin{array}{c}\text { Wald } \\
(3) \\
\end{array}$ & $\begin{array}{c}\mathrm{f} \\
(4) \\
\end{array}$ & $\begin{array}{l}\text { Sig. } \\
(5)\end{array}$ & $\begin{array}{c}\operatorname{Exp}(B) \\
(6)\end{array}$ \\
\hline Status Dalam Rumah Tangga (1) & 0.521 & 85.951 & 1 & 0.000 & 1.684 \\
\hline Status Dalam Rumah Tangga (2) & 0.289 & 82.808 & 1 & 0.000 & 1.335 \\
\hline Status Dalam Rumah Tangga (3) & 0.092 & 7.032 & 1 & 0.008 & 1.097 \\
\hline Jenis Kelamin & 0.102 & 168.318 & 1 & 0.000 & 1.108 \\
\hline umur & & 149.844 & 2 & 0.000 & \\
\hline umur (1) & 0.197 & 45.101 & 1 & 0.000 & 1.217 \\
\hline umur (2) & 0.665 & 61.051 & 1 & 0.000 & 1.945 \\
\hline Kepemilikan NIK & 0.633 & 64.996 & 1 & 0.000 & 1.883 \\
\hline Tingkat Pendidikan & & 663.705 & 2 & 0.000 & \\
\hline Tingkat Pendidikan (1) & 0.540 & 607.399 & 1 & 0.000 & 1.716 \\
\hline Tingkat Pendidikan (2) & 0.536 & 594.081 & 1 & 0.000 & 1.709 \\
\hline Lapangan Usaha & & 172.961 & 2 & 0.000 & \\
\hline Lapangan Usaha (1) & -0.026 & 2.358 & 1 & 0.125 & 0.974 \\
\hline Lapangan Usaha (2) & -0.134 & 62.553 & 1 & 0.000 & 0.874 \\
\hline Keluhan Kesehatan & -0.369 & 651.105 & 1 & 0.000 & 0.691 \\
\hline Status Ekonomi & & 230.294 & 2 & 0.000 & \\
\hline Status Ekonomi (1) & 0.030 & 6.411 & 1 & 0.011 & 1.030 \\
\hline Status Ekonomi (2) & -0.093 & 66.624 & 1 & 0.000 & 0.911 \\
\hline Pengobatan Sendiri & -0.345 & 476.347 & 1 & 0.000 & 0.708 \\
\hline Konstanta & 1.115 & 790.865 & 1 & 0.000 & 3.048 \\
\hline
\end{tabular}

Sumber: SUSENAS KOR 2018, Diolah.

\section{Pembentukan Persamaan Regresi Logistik}

Dari output SPSS diperoleh persamaan regresi logistik yang terbentuk dari variabelvariabel bebas yang signifikan dalam model sebagai berikut:

$$
\begin{aligned}
& \hat{\pi}(D)=\frac{\exp \left(1,115+0,640 D_{1}+0,208 D_{21}+0,036 D_{22}+0,521 D_{31}+0,289 D_{32}\right.}{1+\exp \left(1,115+0,640 D_{1}+0,208 D_{21}+0,036 D_{22}+0,521 D_{31}+0,289 D_{32}\right.} \\
& \frac{+0,092 \mathrm{D}_{33}+0,102 \mathrm{D}_{4}+0,197 \mathrm{D}_{51}+0,665 \mathrm{D}_{52}+0,633 \mathrm{D}_{6}+0,540 \mathrm{D}_{71}}{+0,092 \mathrm{D}_{33}+0,102 \mathrm{D}_{4}+0,197 \mathrm{D}_{51}+0,665 \mathrm{D}_{52}+0,633 \mathrm{D}_{6}+0,540 \mathrm{D}_{71}} \\
& \frac{+0,536 D_{72}-0,134 D_{82}-0,369 D_{9}+0,030 D_{101}-0,093 D_{102}-0,345 D_{11}}{+0,536 D_{72}-0,134 D_{82}-0,369 D_{9}+0,030 D_{101}-0,093 D_{102}-0,345 D_{11}}
\end{aligned}
$$

Persamaan regresi di atas merupakan persamaan regresi non linier. Setelah dilakukan transformasi logit, diperoleh persamaan regresi logistik dari peluang regresi logistik yang linier seperti di bawah ini:

$$
\begin{gathered}
\ln \left(\frac{p}{1-p}\right)=1,115+0,640 D_{1}+0,208 D_{21}+0,036 D_{22}+0,521 D_{31}+0,289 D_{32} \\
\quad+0,092 D_{33}+0,102 D_{4}+0,197 D_{51}+0,665 D_{52}+0,633 D_{6}+0,540 D_{71} \\
\quad+0,536 D_{72}-0,134 D_{82}-0,369 D_{9}+0,030 D_{101}-0,093 D_{102}-0,345 D_{11}
\end{gathered}
$$

Dimana:

$\mathrm{p} \quad$ : peluang pekerja sektor informal untuk memiliki jaminan kesehatan

$\mathrm{X}_{1} \quad$ : wilayah tempat tinggal 


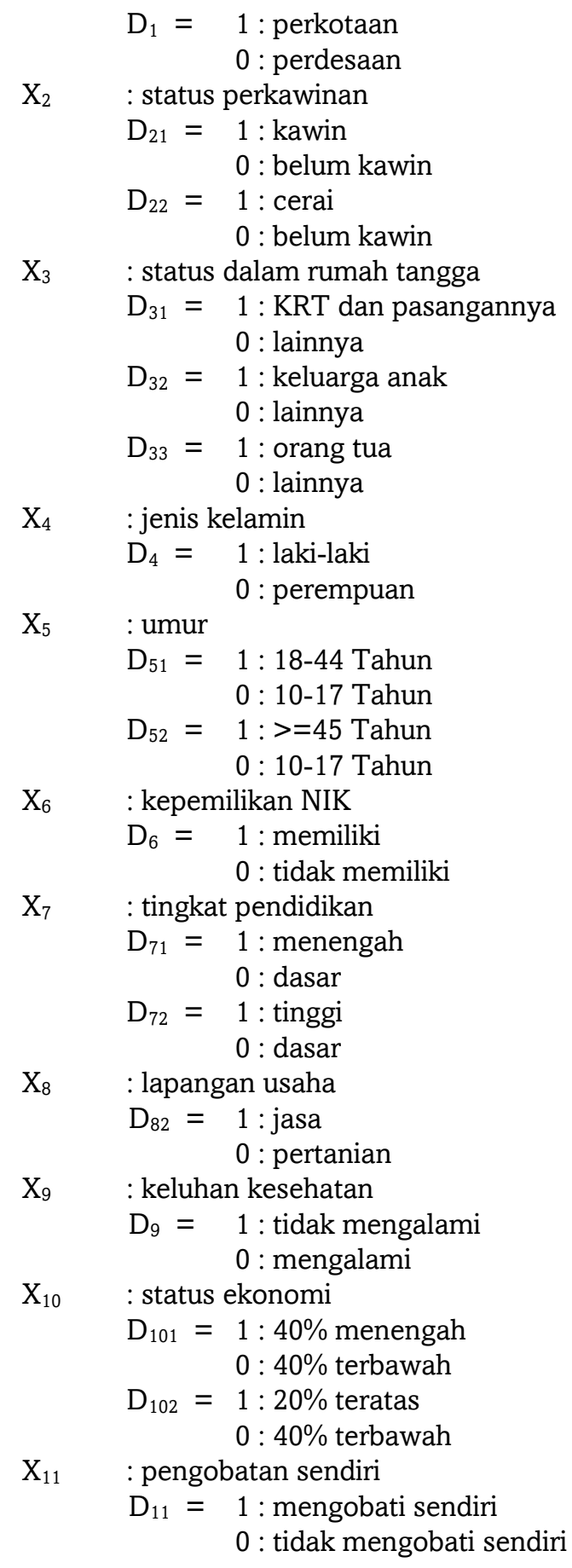

Persamaan regresi logistik yang diperoleh dapat digunakan untuk memperkirakan besarnya peluang pekerja sektor informal untuk memiliki jaminan kesehatan dengan karakteristik tertentu sesuai dengan variabel di atas. Tanda koefisen dapat menunjukkan besarnya peluang suatu kategori, dimana tanda positif menunjukkan peluang suatu kategori lebih besar daripada kategori pembanding. Sebaliknya tanda koefisien negatif berarti peluang kategori tersebut lebih kecil daripada kategori pembanding.

Persamaan di atas menunjukkan nilai intercept $=1,115$, ini berarti saat semua variabel bebas bernilai 0 , yaitu saat pekerja sektor informal memiliki karakteristik sebagai berikut: perempuan yang tinggal di perdesaan, berstatus belum kawin, dalam rumah tangga sebagai famili lain, berumur 10-17 tahun, tidak memiliki NIK, berpendidikan SD atau tidak 
tamat SD atau belum pernah sekolah, bekerja di sektor pertanian, tidak mengalami keluhan kesehatan, tingkat kesejahteraan keluarganya tergolong rendah (40\% terbawah), dan tidak melakukan pengobatan sendiri maka peluang pekerja sektor informal tersebut untuk memiliki jaminan kesehatan adalah sebesar :

$$
\begin{aligned}
& \ln \left(\frac{\mathbf{p}}{\mathbf{1}-\mathbf{p}}\right)=1,115 \\
& \frac{\mathbf{p}}{\mathbf{1 - p}}=\exp (1,115) \\
& \mathrm{p}=\frac{\exp (1,115)}{1-\exp (1,115)} \\
& p=-1,487
\end{aligned}
$$

Dengan kata lain, bahwa peluang seorang pekerja sektor informal dengan karakteristik tersebut di atas untuk memiliki jaminan kesehatan adalah sebesar $-148,7$ persen. Tanda negatif dalam hal ini berarti peluangnya untuk memiliki jaminan kesehatan amat sangat kecil. $\mathrm{Hal}$ ini sangat masuk, karena memang individu dengan kategori yang dijadikan reference category dari masing-masing variabel memang yang pada umumnya peluangnya sangat kecil untuk memiliki jaminan kesehatan.

Ketepatan model regresi logistik dalam memprediksi data empiris dilihat pada output Classification Table, ditunjukkan pada nilai overall percentage sebesar 74,6 persen. Angka tersebut dapat diartikan bahwa variabel-variabel penjelas dalam model dapat mengkategorikan pekerja sektor informal ke dalam kategori memiliki atau tidak memiliki jaminan kesehatan dengan ketepatan 74,6 persen, sedangkan sisanya sebesar 25,4 persen dipengaruhi oleh variabel lain di luar model. Masih cukup tingginya persentase kontribusi variabel lain di luar model menandakan masih dibutuhkan lebih banyak lagi variabel sehingga dapat lebih menggambarkan faktor-faktor yang memengaruhi kepemilikan jaminan kesehatan khususnya pada pekerja sektor informal di Indonesia. Selain itu, hal ini juga menunjukkan keterbatasan variabel-variabel yang ada dalam data penelitian.

\section{DISKUSI}

Hasil eksponen terhadap nilai estimasi koefisien regresi $\left(\beta_{\mathrm{i}}\right)$ didapatkan nilai odds ratio. Dari nilai odds ratio dapat diketahui besar kecenderungan pekerja sektor informal di Indonesia untuk memiliki jaminan kesehatan berdasarkan faktor-faktor yang memengaruhinya. Dari tabel 2 sebelumnya, nilai odds ratio ditunjukkan dengan besarnya nilai $\operatorname{Exp(B)~sehingga~dapat~dijelaskan~seperti~di~bawah~ini:~}$

\section{Wilayah Tempat Tinggal}

Pekerja sektor informal yang tinggal di wilayah perkotaan memiliki kecenderungan untuk memiliki jaminan kesehatan 1,897 kali lebih besar dibandingkan dengan pekerja sektor informal yang tinggal di wilayah perdesaan. Hal ini sesuai dengan hasil penelitian Intiasari dkk (2015) dan juga Idris (2016) dimana variabel status area berpengaruh positif terhadap kepemilikan jaminan kesehatan baik yang bersifat subsidi maupun kontribusi, atau dengan kata lain bahwa pekerja sektor informal di kota memiliki probabilitas lebih besar dalam kepemilikan jaminan kesehatan subsidi dan kontribusi dibandingkan dengan pekerja sektor informal di desa.

Menurut Kirigia dkk (2005), fenomena di atas merupakan cerminan dari status sosial ekonomi atau kesejahteraan yang lebih baik dari mereka yang hidup di kota dibandingkan kehidupan di desa yang relatif tidak memiliki berbagai fasilitas sosial. Selain itu, Mulenga dkk 
(2017) dalam penelitiannya mengemukakan alasan pekerja sektor informal di perdesaan memiliki peluang lebih rendah untuk memiliki jaminan kesehatan dibandingkan dengan yang tinggal di perkotaan dikarenakan pada umumnya perusahaan asuransi kesehatan sebagian besar ditemukan di daerah perkotaan dan perusahaan-perusahaan ini telah menyesuaikan produk mereka dengan penduduk kota.

Alasan lain yang mendasar disampaikan Thabrani (2008) dalam paparannya yang menyatakan bahwa biaya transportasi di perdesaan seringkali setara dengan 10 kali biaya pengobatan. Situasi ini memperburuk akses terhadap pelayanan kesehatan dan menimbulkan kesenjangan ( $g a p$ ) dan ketidakadilan antara orang kaya dan miskin, orang sakit dan sehat, dan orang yang hidup di wilayah pedesaan dan perkotaan. Selain itu sulitnya akses dan mahalnya biaya transportasi juga membuat jaminan kesehatan kurang bernilai karena sulit dimanfaatkan sehingga pekerja sektor informal yang ada di desa kurang merasa perlu untuk memiliki jaminan kesehatan.

Temuan penelitian di beberapa negara di dunia seperti di wilayah pedesaan Iran didapatkan hasil bahwa kondisi sarana maupun prasarana di suatu wilayah tersebut yang memberikan andil besar terhadap kontribusi pada jaminan kesehatan. Keberadaan unit perawatan kesehatan, keberadaan dokter secara penuh di desa, jarak terdekat ke rumah sakit, dan kepuasan fasilitas perawatan kesehatan memiliki pengaruh signifikan pada kesediaan rumah tangga untuk membayar jaminan kesehatan (Asgary dkk, 2004). Masih berkaitan erat dengan temuan di atas, semakin jauh jarak dari pusat kesehatan dan tidak tersedianya layanan kesehatan yang berkualitas (termasuk kurangnya obat-obatan dan rendahnya kualitas pelayanan) berdampak negatif pada permintaan untuk jaminan kesehatan (Carrin, 2003 dan Dror dkk, 2016).

\section{Status Perkawinan}

Pekerja sektor informal yang berstatus kawin memiliki kecenderungan untuk memiliki jaminan kesehatan 1,231 kali lebih besar dibandingkan dengan pekerja sektor informal yang berstatus belum kawin. Sedangkan pekerja sektor informal yang berstatus cerai memiliki kecenderungan untuk memiliki jaminan kesehatan 1,037 kali lebih besar dibandingkan dengan pekerja sektor informal yang berstatus belum kawin. Kedua kondisi tersebut dapat juga berarti bahwa pekerja sektor informal yang sudah menikah ataupun pernah menikah/cerai hidup/cerai mati lebih mungkin untuk memiliki jaminan kesehatan daripada mereka yang lajang atau belum menikah.

Temuan di atas konsisten dengan hasil penelitian yang diperoleh oleh Rhine (1998), Harmon dkk (2001), dan Trujillo (2003) bahwa pasangan menikah atau pernah menikah lebih memungkinkan memiliki permintaan yang lebih tinggi untuk asuransi atau jaminan kesehatan dikarenakan: (i) kebutuhan untuk melindungi anak-anak mereka; (ii) memiliki pendapatan gabungan yang lebih tinggi pada pekerja yang memiliki pasangan apabila keduanya bekerja; dan (iii) lebih mampu untuk menanggulangi pengeluaran kesehatan yang sangat besar (katastropik) dibandingkan mereka yang lajang atau belum menikah.

Selain itu, alasan mengapa kecenderungan pekerja sektor informal yang menikah lebih besar dibandingkan dengan yang berstatus cerai dalam hal kepemilikan jaminan kesehatan dapat dijelaskan melalui teori marriage protection (Wilson dkk, 2005). Teori ini menjelaskan hubungan status pernikahan dan status kesehatan dimana dengan menikah, individu mampu memiliki tambahan penghasilan yang dapat digunakan dalam membiayai pengeluaran kesehatan termasuk di dalamnya jaminan kesehatan. Selain itu, menikah juga mampu mengurangi stress karena terdapat rasa cinta dan berbagi dengan pasangan serta dengan menikah mampu membuat pasangan lebih memperhatikan kondisi kesehatan satu sama lain sehingga bisa mengurangi kecenderungan gaya hidup yang buruk. Hal ini berbeda dengan orang yang bercerai, dimana menurut Pandey (2008) dan Yamamura (2009) perceraian akan 
memberikan dampak yang buruk terhadap kesehatan seperti depresi serta peningkatan dalam hal konsumsi obat-obatan.

\section{Status Dalam Rumah Tangga}

Pekerja sektor informal yang berstatus sebagai kepala rumah tangga ataupun pasangannya memiliki kecenderungan untuk memiliki jaminan kesehatan 1,684 kali lebih besar dibandingkan dengan pekerja sektor informal yang berstatus lainnya (pembantu/sopir/lainnya). Pekerja sektor informal yang mempunyai status sebagai keluarga anak keluarga anak (anak kandung/tiri, anak angkat, menantu, dan cucu) memiliki kecenderungan untuk memiliki jaminan kesehatan 1,335 kali lebih besar dibandingkan dengan pekerja sektor informal yang berstatus lainnya (pembantu/sopir/lainnya). Sedangkan pekerja sektor informal yang berstatus sebagai orang tua/mertua memiliki kecenderungan untuk memiliki jaminan kesehatan 1,097 kali lebih besar dibandingkan dengan pekerja sektor informal yang berstatus lainnya (pembantu/sopir/lainnya). Jadi intinya hasil penelitian ini menunjukkan hasil bahwa kecenderungan pembantu/sopir dan lainnya paling kecil dalam hal kepemilikan jaminan kesehatan dibandingkan kategori lainnya. Hasil ini bertolak belakang dengan penelitian Intiasari dkk (2015) yang menyatakan bahwa pembantu memiliki kemungkinan paling tinggi untuk memiliki asuransi kesehatan komersial, setelah itu disusul oleh istri/suami di posisi tertinggi kedua.

Namun, beberapa penelitian di dunia terkait kepemilikan jaminan kesehatan didapatkan hasil yang sejalan dengan hasil analisis data di atas walaupun terdapat sedikit perbedaan. Menurut hasil penelitian Edoh dkk (2004) yang melakukan penelitian di Ghana didapatkan hasil bahwa dalam satu keluarga, anggota keluarga yang lebih muda bersedia membayar lebih untuk premi asuransi anggota keluarga lainnya termasuk orang tua sehingga ia yang paling besar kemungkinannya untuk memiliki jaminan kesehatan. Sedangkan penelitian Asgary dkk (2004) di Iran dan Nigeria justru didapatkan hasil bahwa semakin tua umur seseorang dalam rumah tangga dalam hal ini kepala rumah tangga, maka ia akan lebih bersedia untuk membayarkan biaya asuransi anggota rumah tangga lainnya. Dalam hal ini maka peluang terbesar ada pada orang tua sebagai kepala keluarga untuk memiliki jaminan kesehatan. Sedangkan sebuah penelitian di Bangladesh didapatkan hasil bahwa orang tua mungkin memiliki kapasitas lebih sedikit untuk membayar premi jaminan kesehatan ketimbang anggota keluarga lainnya (Ahmed dkk, 2016).

Skema asuransi atau jaminan kesehatan terkadang memandang seorang perempuan sebagai istri atau ibu daripada sebagai individu atau pekerja, padahal hak individu atas asuransi sosial sangat penting. Jika akses perempuan untuk asuransi sosial atau jaminan kesehatan datang melalui suami mereka, ini dapat memberikan perlindungan dalam keluarga tetapi bukan otonomi perempuan, begitu juga anak (Arza, 2012). Ini menimbulkan satu lagi masalah, bahwa polis asuransi dapat memperlakukan keluarga sebagai satu unit, dengan asumsi bahwa pendapatan dan manfaat dibagikan dalam keluarga. Namun, karena perempuan seringkali memiliki status yang lebih rendah dan kurang kontrol atas pengambilan keputusan, seperti pendekatan resiko sehingga ini menjadi tidak menguntungkan bagi perempuan. Pada di tingkat masyarakat dan tingkat sosial yang lebih luas, norma sosial budaya mungkin membatasi gerakan perempuan di luar rumah, atau menghasilkan tingkat pendidikan dan keterampilan yang lebih rendah. Ini dapat membatasi akses perempuan untuk untuk mendaftar pada skema jaminan sosial atau jaminan kesehatan, atau membatasi pengetahuan mereka tentang proses aplikasi, klaim dan manfaat dari jaminan tersebut. 


\section{Jenis Kelamin}

Pekerja sektor informal berjenis kelamin laki-laki memiliki kecenderungan untuk memiliki jaminan kesehatan 1,108 kali lebih besar dibandingkan dengan pekerja sektor informal berjenis kelamin perempuan. Temuan ini konsisten dengan penelitian Suharto (2009) dimana sangat banyak kaum perempuan yang bekerja di sektor informal dan pekerjaan tanpa gaji. Hal ini dapat diakibatkan perempuan lebih rentan terhadap berbagai resiko terkait dengan siklus kehidupannya dan peranannya di dalam keluarga. Akan tetapi, karena mereka lebih banyak terlibat dalam kegiatan ekonomi informal, ironisnya mereka lebih tidak dilindungi oleh skema jaminan sosial khususnya kesehatan. Selain itu, berdasarkan penelitian Kwadwo dkk (1997) di Ghana dan Ataguba dkk (2008) di Nigeria jika dilihat dari kontribusi pembayaran premi maka laki-laki bersedia membayar jumlah yang lebih tinggi untuk jaminan kesehatan daripada perempuan, maka hal ini juga yang menyebabkan kepemilikan jaminan kesehatan lebih tinggi pada laki-laki.

Menurut Holmes dkk (2016) stigma yang secara umum menganggap bahwa perempuan cenderung terlalu mewakili dalam pekerjaan rumah tangga atau pekerjaan berbasis rumahan, maupun sebagai pekerja yang berkontribusi tidak dibayar khususnya dalam bidang pertanian membuat mereka semakin sulit untuk memiliki jaminan kesehatan. Selain itu, skema asuransi sosial atau jaminan kesehatan juga merasa lebih sulit untuk menanggung perempuan karena resiko siklus hidup spesifik yang dihadapi perempuan dimana perempuan memiliki kebutuhan layanan kesehatan yang lebih besar seperti kesehatan reproduksi misalnya, tetapi jaminan kesehatan mungkin tidak memasukkan layanan tersebut. Sementara itu, fakta bahwa perempuan hidup lebih lama menghasilkan tantangan yang lebih besar bagi penyedia jasa jaminan kesehatan. Kemungkinan seorang perempuan yang menjadi janda juga lebih tinggi dari seorang laki-laki yang menjadi duda, karena umur rata-rata perempuan lebih lama dan juga karena dalam beberapa budaya perempuan menikahi laki-laki yang bertahun-tahun lebih tua dari mereka.

Chen dkk (2015) dalam penelitiannya di Bangkok (Thailand) dan Ahmedabad (India) menemukan perbedaan yang mencolok antara pekerja informal (pekerja berbasis rumahan, pedagang kaki lima, dan pemulung) laki-laki dan perempuan, dimana pekerja perempuan mengurangi jam kerjanya dari minggu sebelumnya untuk merawat anak-anak, orang sakit, atau orang tua, sedangkan laki-laki tidak melakukannya. Hal ini menyebabkan kontribusi perempuan dalam hal pekerjaan dan pendapatan menjadi lebih rendah sebagai akibat dari tanggung jawab perawatan yang menyebabkan partisipasi perempuan dalam skema jaminan sosial juga rendah. Selain itu, perempuan mungkin juga memiliki lebih sedikit akses informasi tentang skema jaminan sosial dibandingkan laki-laki serta menyebarkan informasi kepada perempuan bisa lebih sulit karena mereka lebih cenderung bekerja di rumah. Disamping itu perempuan mungkin memiliki lebih sedikit waktu untuk berurusan dengan proses administrasi jaminan kesehatan untuk mengajukan permohonan skema karena pekerjaan dan perawatan serta tanggung jawab pekerjaan, di luar itu mobilitas yang terbatas juga menjadi kendala.

Mulenga dkk (2017) dalam penelitiannya juga mengaitkan rendahnya kepemilikan jaminan kesehatan pada perempuan khususnya yang telah menikah dimana penjelasan yang masuk akal untuk hal ini adalah bahwa perempuan yang telah menikah dapat mengambil manfaat dari polis asuransi kesehatan suami mereka ketika mereka jatuh sakit dan ingin memanfaatkan asuransi atau jaminan kesehatan sehingga perempuan tersebut tidak perlu membuat atau memiliki jaminan kesehatan sendiri.

\section{Umur}

Pekerja sektor informal berumur 18-44 tahun memiliki kecenderungan untuk memiliki jaminan kesehatan 1,217 kali lebih besar dibandingkan dengan pekerja sektor informal 
berumur 10-17 tahun. Sedangkan pekerja sektor informal berumur $>=45$ tahun memiliki kecenderungan untuk memiliki jaminan kesehatan 1,945 kali lebih besar dibandingkan dengan pekerja sektor informal berumur 10-17 tahun.

Kirigia dkk (2005) menyatakan bahwa seiring bertambahnya usia, kualitas kesehatan selalu mengalami penurunan pada tingkat yang semakin besar (manifestasi dari proses penuaan biologis) dan individu cenderung meningkatkan investasi dalam hal kesehatan (termasuk asuransi kesehatan) dalam upaya untuk mengurangi tingkat penyusutan. Hal ini konsisten dengan temuan Grossman (1972) bahwa tingkat penurunan kualitas kesehatan semakin besar dengan bertambahnya usia, maka tidak mustahil orang yang tidak dalam keadaan sehat (tua) akan melakukan investasi yang lebih besar pada aspek kesehatan daripada orang yang sehat (muda). Alasan di atas didukung dengan temuan Handajani dkk (2010) yang menyatakan bahwa kematian penyakit degeneratif terbanyak pada usia 45 tahun keatas yang dimungkinkan karena terjadinya perubahan demografi dan komposisi umur, dimana kejadian penyakit degeneratif (terutama diabetes) akan merata pada semua golongan umur.

\section{Kepemilikan NIK}

Pekerja sektor informal yang memiliki NIK memiliki kecenderungan untuk memiliki jaminan kesehatan 1,883 kali lebih besar dibandingkan dengan pekerja sektor informal yang tidak memiliki NIK. Jaminan Kesehatan telah menjadi salah satu agenda pembangunan yang sangat penting bukan hanya di Indonesia tetapi juga dunia. Salah satu target utama cakupan jaminan kesehatan adalah memenuhi kebutuhan kelompok miskin dan rentan termasuk di dalamnya pekerja di sektor informal. Namun, menurut Asian Development Bank (2016) masih terdapat beberapa kendala yang membatasi partisipasi pekerja sektor informal di jaminan kesehatan diantaranya kesadaran yang terbatas tentang konsep perlindungan sosial, keengganan untuk membayar premi asuransi, skema asuransi yang kurang fleksibel karena membutuhkan dokumentasi untuk mengklaim manfaat, serta dokumentasi untuk pendaftaran, pengumpulan kontribusi, dan pencatatan. Dalam hal ini dokumentasi adalah identitas individu yang mendasar terutama Nomor Induk Kependudukan (NIK).

Masih banyaknya pekerja sektor informal yang tidak memiliki dokumen individu dan sebagian dari mereka berstatus sebagai migran yang menghambat masuknya pekerja sektor informal dalam skema jaminan sosial. Hal senada juga disampaikan Ginneken (2002) dimana terdapat berbagai faktor yang membatasi pekerja sektor informal kepada akses skema/pendaftaran jaminan kesehatan, beberapa yang terpenting adalah pembatasan hukum dan hambatan administrasi. Hambatan administrasi di sini yaitu berbagai dokumen pribadi individu yang sah.

Menurut Undang-Undang Republik Indonesia Nomor 24 Tahun 2013 Tentang Perubahan Atas Undang-Undang Nomor 23 Tahun 2006 Tentang Administrasi Kependudukan, Nomor Induk Kependudukan selanjutnya disingkat NIK adalah nomor identitas Penduduk yang bersifat unik atau khas, tunggal dan melekat pada seseorang yang terdaftar sebagai Penduduk Indonesia. Dalam mekanisme pendaftaran berbagai jaminan kesehatan atau asuransi baik milik pemerintah atau swasta diperlukan informasi kependudukan terutama NIK. Hal ini juga yang mendasari Badan Penyelenggara Jaminan Sosial (BPJS) Kesehatan yang memanfaatkan NIK untuk mencegah adanya duplikasi data kepesertaan serta mencapai Universal Health Coverage (UHC). Berdasarkan data kependudukan ini, maka bisa menjadi dasar apakah data kepesertaan yang telah didaftar sudah akurat atau tidak. NIK bisa menjadi keyword dalam kepesertaan untuk mencegah adanya duplikasi data kepesertaan (BPJS Kesehatan, 2017). 


\section{Tingkat Pendidikan}

Pekerja sektor informal yang berpendidikan menengah memiliki kecenderungan untuk memiliki jaminan kesehatan 1,716 kali lebih besar dibandingkan dengan pekerja sektor informal berpendidikan dasar. Sedangkan pekerja sektor informal berpendidikan perguruan tinggi memiliki kecenderungan untuk memiliki jaminan kesehatan yang hampir sama dengan pendidikan menengah yaitu 1,709 kali lebih besar dibandingkan dengan pekerja sektor informal berpendidikan dasar. Kedua hasil ini sejalan dengan penelitian Mulenga dkk (2017) bahwa pendidikan memainkan peran penting yaitu dapat mencerahkan individu tentang pentingnya cakupan asuransi kesehatan. Pendidikan juga membantu individu membuat pilihan berdasarkan informasi tentang masalah kesehatan, di antaranya pembelian asuransi kesehatan untuk menghindari pengeluaran kesehatan yang sangat besar ketika mereka jatuh sakit.

Keterkaitan antara tingkat pendidikan dengan kepemilikan jaminan kesehatan telah dibuktikan dalam beberapa penelitian terdahulu. Gerungan (2004) berpendapat bahwa semakin tinggi pendidikan akan memengaruhi pribadi seseorang dalam berfikir, bersikap, mengambil keputusan, termasuk dalam merencanakan kesehatan salah satunya yaitu dengan mengikuti JKN. Pendapat ini diperkuat dengan hasil kajian yang dilakukan Amu \& Dickson (2018) di Ghana yang menunjukkan bahwa masyarakat berpendidikan tinggi memiliki pandangan yang lebih tinggi berkaitan dengan perlunya memiliki asuransi kesehatan untuk menghadapi masalah kesehatan yang tidak terduga, sedangkan masyarakat berpendidikan rendah tidak menyadari tingkat ancaman yang akan ditimbulkan terkait masalah kesehatan yang tidak terduga.

Hubungan level pengetahuan seseorng yang dapat dicerminkan lewat tingkat pendidikan dalam hal preferensi kepemilikan jaminan kesehatan juga dapat dijelaskan lewat teori utilitas yang diharapkan. Marquis dkk (1996) menjelaskan bahwa lewat teori utilitas yang diharapkan, individu akan mampu membandingkan manfaat yang didapatkan dengan membeli asuransi atau jaminan kesehatan dengan pengeluaran perawatan kesehatan jika tanpa asuransi atau jaminan kesehatan. Kalau manfaat asuransi lebih besar daripada biaya yang dikeluarkan, individu cenderung membeli asuransi kesehatan. Berbagai manfaat asuransi terungkap terutama ketika individu jatuh sakit, demikian juga pengetahuan dan perkiraan kondisi kesehatan masa mereka di masa depan diharapkan mampu memberikan dampak signifikan pada keputusan mereka untuk membeli asuransi kesehatan. Oleh karena itu, ketika biaya perawatan kesehatan sangat tinggi dan harapan individu untuk sembuh dari penyakit juga tinggi, akan lebih tinggi kemungkinan seseorang untuk membeli asuransi atau jaminan kesehatan.

Menurut Liu dkk (2002) hubungan positif antara pekerja sektor informal dengan tingkat pendidikannya dapat dijelaskan sebagai berikut: (i) tingkat pendidikan yang tinggi dapat diasosiasikan dengan tingkat keterampilan yang juga tinggi sehingga memungkinkan pekerja sektor informal dapat lebih kreatif demi mendapatkan penghasilan yang lebih tinggi; (ii) level pengetahuan yang tinggi dapat membuat pekerja lebih jeli dalam menganalisis pasar walaupun pengalaman disini juga turut berperan; dan (iii) pendidikan dan pengetahuan yang baik dapat mempertimbangkan keuntungan jangka panjang dimana melakukan pembayaran asuransi kecil secara reguler untuk menghindari resiko pengeluaran medis yang sangat besar di kemudian hari.

\section{Lapangan Usaha}

Pekerja sektor informal pada lapangan usaha pertanian memiliki kecenderungan untuk memiliki jaminan kesehatan $(1 / 0,874)$ atau 1,144 kali lebih besar dibandingkan dengan pekerja sektor informal pada lapangan usaha jasa. Hal tersebut bukan tanpa alasan mengingat lapangan usaha pertanian merupakan salah satu sektor yang paling berbahaya 
untuk bekerja, dengan tingkat kecelakaan fatal yang tinggi dan risiko paparan pestisida dan bahan kimia yang tinggi maka jaminan kesehatan mutlak dibutuhkan (Holmes dkk, 2016).

Berdasarkan data ILO (2008) dalam Suharto (2009), kepesertaan asuransi kesehatan sektor formal sangat didominasi oleh pekerja di sektor publik (PNS, ABRI) dan pekerja sektor formal yang bekerja di perusahaan-perusahaan besar. Sedangkan kepesertaan jaminan kesehatan pada sektor informal didominasi oleh petani, nelayan, dan sejenisnya. Cedera merupakan salah satu faktor yang berkontribusi terhadap masalah kesehatan dan disabilitas. Penelitian yang dilakukan oleh Tana (2015) untuk melihat faktor yang berperan pada lama rawat inap akibat cedera pada kelompok pekerja usia produktif di Indonesia, didapatkan hasil bahwa jenis pekerjaan utama sebagai petani, nelayan, dan sejenisnya lebih sering mengalami cedera dibandingkan pegawai. Tentu saja kondisi ini akan berpengaruh terhadap kepemilikan serta penggunaan jaminan kesehatan.

Sedangkan variabel lapangan usaha kategori industri tidak berpengaruh signifikan terhadap variabel kepemilikan jaminan kesehatan karena nilai signifikansinya sebesar 0,131 atau lebih besar dari 0,05. Hal ini dikarenakan pekerja pada sektor industri membutuhkan tidak hanya sekedar jaminan kesehatan tetapi lebih dari itu. Hasil tulisan Ilyas (2005) dalam Idris (2016) menyatakan bahwa berbagai penyakit dapat timbul disebabkan pekerjaan terutama pada sektor industri. Di Amerika, pekerjaan merupakan faktor signifikan dalam asuransi long term disability karena banyak pekerjaan yang membawa risiko kecelakaan dan cacat. Oleh karena itu jaminan sosial yang tepat digunakan pada pekerjaan di sektor industri adalah jaminan yang di dalamnya terdapat manfaat pertanggungan kecelakaan kerja sekaligus di dalamnya ada manfaat kesehatan juga, dimana di Indonesia jaminan sosial yang mempunyai manfaat tersebut adalah BPJS Ketenagakerjaan atau yang sejenis.

\section{Keluhan Kesehatan}

Pekerja sektor informal yang mengalami keluhan kesehatan memiliki kecenderungan untuk memiliki jaminan kesehatan (1/0,691) atau 1,447 kali lebih besar dibandingkan dengan pekerja sektor informal yang tidak mengalami keluhan kesehatan. Hasil ini sejalan dengan penelitian Kirigia dkk (2005) dimana permintaan untuk asuransi kesehatan cenderung rendah di antara individu atau pekerja yang berada dalam kesehatan yang sangat baik atau tidak mengalami keluhan maupun gangguan kesehatan. Selain itu, sebuah laporan penelitian di Ghana bahwa orang-orang dengan kondisi kesehatan yang buruk lebih mungkin untuk membeli jaminan kesehatan (Acharya dkk, 2012). Alasannya adalah orang yang berisiko tinggi untuk mengalami sakit akan melihat manfaat yang diharapkan juga lebih tinggi dari keikutsertaannya dalam jaminan kesehatan dibandingkan dengan tingkat kontribusi yang dibayarkannya (Bundorf dkk, 2006). Alasan lainnya yang mendasari mengapa sangat banyak pekerja sektor informal yang sama sekali tidak terdaftar dalam skema jaminan kesehatan selain karena mereka tidak mengerti nilai asuransi atau juga karena mereka sehat dan tidak mungkin menggunakan layanan jaminan kesehatan (Schieber dkk, 2012).

Idris (2016) dalam tulisannya juga menyatakan bahwa seseorang akan membeli asuransi atau jaminan kesehatan jika ia menyadari bahwa ia memiliki resiko untuk jatuh sakit dan akan mengalami kerugian finansial akibat dari sakit tersebut. Orang dengan resiko jatuh sakit yang cukup sering akan membutuhkan asuransi dibandingkan dengan orang yang jarang sakit. Penelitian yang sejalan yaitu dilakukan oleh Madya dkk (2018) yang mendapatkan hasil bahwa tidak adanya keluhan kesehatan pada tenaga kerja informal berpeluang menurunkan kepemilikan jaminan kesehatan hampir 50 persen. Kirui (2012) juga mengungkapkan hal senada dimana dalam asuransi swasta, orang-orang yang berada dalam kelompok risiko kesehatan tinggi (memiliki keluhan/gangguan kesehatan tinggi) rela membayar lebih untuk asuransi kesehatan sedangkan mereka yang berisiko rendah (memiliki 
keluhan/gangguan kesehatan rendah) membayar lebih sedikit untuk asuransi kesehatannya atau bahkan tidak terlalu memperdulikan masalah asuransi kesehatan.

\section{Status Ekonomi}

Pekerja sektor informal dengan status ekonomi 40\% menengah memiliki kecenderungan untuk memiliki jaminan kesehatan 1,030 kali lebih besar dibandingkan dengan pekerja sektor informal dengan status ekonomi 40\% terbawah. Status ekonomi yang semakin baik menandakan tingkat pendapatan yang juga semakin baik sehingga memberikan akses seseorang dalam memiliki asuransi kesehatan dan memanfaatkan pelayanan kesehatan. Peningkatan pendapatan akan berhubungan positif dengan peningkatan status kesehatan (Booth dkk, 2005; Tubeuf dkk, 2008). Rendahnya status ekonomi dapat menggambarkan kenyataan bahwa sebagian besar dari mereka belum menyadari perlunya iuran untuk jaminan kesehatan dan bahkan belum mengerti apa itu jaminan kesehatan. Upah yang rendah memberikan keterbatasan akses terhadap pendidikan, makanan yang bergizi, penyediaan tempat tinggal yang layak dan juga pelayanan kesehatan yang berkualitas (Intiasari dkk, 2015).

Kurangnya uang atau rendahnya pendapatan pekerja sektor informal memang merupakan alasan utama mengapa banyak yang tidak bergabung dalam jaminan kesehatan, dibandingkan dengan individu pada kuintil berpenghasilan tinggi yang lebih mungkin untuk masuk dan ditanggung oleh jaminan kesehatan (Carrin dkk, 2005). Sebuah studi di Ghana menunjukkan bahwa sebuah pembiayaan asuransi rumah tangga secara penuh akan membebani rumah tangga dengan status sosial ekonomi rendah dan rumah tangga dengan jumlah anggota rumah tangga yang besar (Kusi dkk, 2015). Temuan serupa di Iran juga mengungkapkan bahwa rumah tangga yang relatif lebih makmur di wilayah perkotaan akan mampu membayar lebih besar untuk asuransi kesehatan (Nosratnejad dkk, 2014). Namun, terdapat beberapa kondisi dimana rumah tangga dengan status sosial ekonomi rendah membelanjakan sejumlah besar dana yang dimiliki untuk kebutuhan perawatan kesehatan dan untuk jaminan kesehatan. Mereka mungkin bersedia membayar untuk jaminan kesehatan jika memiliki harapan besar bahwa jaminan kesehatan akan memberikan perlindungan yang efektif terhadap kesehatan, kemiskinan dan pengeluaran yang disebabkan bencana (Schneider, 2004).

Tidak semua penelitian menghasilkan kesimpulan bahwa tingkat pendapatan atau status ekonomi yang tinggi selalu berpengaruh terhadap kepemilikan jaminan kesehatan dan status kesehatan yang tinggi. Seperti kondisi pekerja sektor informal dengan status ekonomi $40 \%$ terbawah justru memiliki kecenderungan untuk memiliki jaminan kesehatan $(1 / 0,911)$ atau 1,097 kali lebih besar dibandingkan dengan pekerja sektor informal dengan status ekonomi $20 \%$ teratas. Rumah tangga berpendapatan tinggi biasanya enggan untuk bergabung dengan skema asuransi atau jaminan kesehatan karena mereka tidak terlalu menyukai prinsip asuransi yaitu membayar sesuatu untuk layanan yang mungkin tidak mereka gunakan (Brown dkk, 2000).

Hubungan negatif tingkat pendapatan terhadap kepemilikan dan status kesehatan juga dapat dijelaskan melalui ketersediaan fasilitas kesehatan publik. Jika tingkat pendapatan masyarakat rendah namun ketersediaan fasilitas publik di suatu masyarakat memadai dan berkualitas atau tersedia asuransi untuk masyarakat pada kelas ekonomi bawah, maka tingkat pendapatan dapat menjadi tidak berpengaruh secara signifikan atau bahkan berpengaruh negatif terhadap kesehatan (Chung, 2004).

\section{Pengobatan Sendiri}

Pekerja sektor informal yang tidak melakukan pengobatan sendiri memiliki kecenderungan untuk memiliki jaminan kesehatan $(1 / 0,708)$ atau 1,412 kali lebih besar 
dibandingkan dengan pekerja sektor informal yang melakukan pengobatan sendiri. Hal ini senada dengan apa yang BPS (2017) sampaikan dalam publikasinya bahwa rendahnya kepemilikan jaminan kesehatan di Indonesia selain dipengaruhi oleh drendahnya pengetahuan penduduk juga disebabkan masih banyaknya penduduk Indonesia yang melakukan pengobatan sendiri ketika mereka mengalami keluhan kesehatan atau bahkan mengabaikan sakit yang mereka derita. Oleh karena itu, mereka merasa tidak perlu memiliki jaminan kesehatan karena mereka tidak mencari pengobatan ke fasilitas kesehatan.

Perilaku pencarian perawatan kesehatan mengacu pada keputusan atau tindakan yang diambil oleh seorang individu untuk mencari layanan perawatan kesehatan untuk mengobati penyakit. Keputusan yang dibuat terdiri dari semua pilihan perawatan kesehatan yang tersedia, seperti mengunjungi fasilitas kesehatan publik atau swasta, pengobatan sendiri dan penggunaan pengobatan rumahan, atau tidak memanfaatkan layanan kesehatan yang tersedia, dll (Chauhan dkk, 2015). Pilihan pengobatan sendiri berdasarkan penelitian yang sudah banyak dilakukan justru lebih kepada alasan teknis dan faktor lain di luar kepemilikan jaminan kesehatan. Lebih dari setengah individu (baik yang diasuransikan maupun yang tidak diasuransikan) telah melakukan pengobatan sendiri untuk penyakit barubaru ini, termasuk kunjungan ke apotek. Salah satu alasan yang dilaporkan adalah dari segi obat-obatan dan kualitas perawatan yang dirasakan buruk pada tingkat kesehatan dasar, seperti obat yang tidak mencukupi, waktu tunggu yang lama, sikap tidak ramah dari staf kesehatan, dan sistem rujukan yang rumit. Tingkat pengobatan sendiri dalam beberapa menunjukkan angka yang cukup besar, seperti penelitian di Gia Lam, Hanoi dimana persentase pengobatan sendiri mencapai 27,5 persen (Bui dkk, 2016), serta temuan dalam penelitian di Cina yang menyatakan bahwa 51,2 persen dari responden tidak menggunakan layanan kesehatan ketika mereka sakit dan lebih memilih melakukan pengobatan sendiri (Fang dkk, 2014).

\section{KESIMPULAN}

Faktor-faktor yang memengaruhi kepemilikan jaminan kesehatan pekerja sektor informal di Indonesia adalah wilayah tempat tinggal, status perkawinan, status dalam rumah tangga, jenis kelamin, umur, kepemilikan NIK, tingkat pendidikan, lapangan usaha, keluhan kesehatan, status ekonomi, dan pengobatan sendiri. Dalam upaya menjalankan amanah SDG's, pemerintah harus terus memperluas jangkauan UHC melalui program-program perlindungan kesehatan bagi pekerja sektor informal. Penting bagi pemerintah dalam memahami faktor-faktor yang memengaruhi individu dalam kepemilikan jaminan kesehatan khususnya pekerja sektor informal yang memiliki proporsi yang cukup besar di Indonesia. Hal tersebut dapat menjadi bahan informasi dan evaluasi untuk menyusun strategi perluasan kepesertaan dalam era jaminan kesehatan nasional (JKN).

\section{DAFTAR PUSTAKA}

Acharya, A., Vellakkal, S., Taylor, F., Masset, E., Satija, A., Burke, M., \& Ebrahim, S. (2012). Impact of national health insurance for the poor and the informal sector in lowand middle-income countries: a systematic review. London: EPPI-Centre, Social Science Research Unit, Institute of Education, University of London.

Ahmed, S., Hoque, M. E., Sarker, A. R., Sultana, M., Islam, Z., Gazi, R., \& Khan, J. A. M. (2016). Willingness-toPay for Community-Based Health Insurance among Informal Workers in Urban Bangladesh. PloS one, 11(20), 1-16.

Ahoobim, O., Altman, D., Garrett, L., Hausman, V., \& Huang, Y. (2012). The New Global Health Agenda: Universal Health Coverage. New York: Council on Foreign Relations.

Amu, H., Dickson, K. S., Kumi-Kyereme, A., \& Darteh, E. K. M. (2018). Understanding variations in health insurance coverage in Ghana, Kenya, Nigeria, and Tanzania: Evidence from demographic and health surveys. PLoS ONE, 13(8), 1-14. 
Arza, C. (2012). Pension Reforms and Gender Equality in Latin America. Geneva: UN Research Institute for Social Development.

Asgary, A., Willis, K., Taghvaei, A. A., \& Rafeian, M. (2004). Estimating rural house-holds' willingness to pay for health insurance. European Journal of Health Economics, 5(3), 209-215.

Asian Development Bank. (2016). Social Protection for Informal Workers in Asia. Philippines: Asian Development Bank.

Ataguba, J., Ichoku, E. H., \& Fonta, W. (2008). Estimating the willingness to pay for community healthcare insurance in rural Nigeria. SSRN Electronic Journal, 33(3), 317-342.

Atmawikarta, A. (2002). Investasi kesehatan untuk pembangunan ekonomi. Jakarta: BAPPENAS.

BPJS Kesehatan. (2017). Dampak Program JKN-KIS pada Perekonomian Indonesia. Jakarta: BPJS Kesehatan. . (2019). Peserta Program JKN per 31 Agustus 2019. Jakarta: BPJS Kesehatan.

Badan Pusat Statistik. (2017). Indikator Kesejahteraan Rakyat 2017. Jakarta: Badan Pusat Statistik.

Boerma, T., Eozenou, P., Evans, D., Evans, T., Kieny, M. P., \& Wagstaff, A. (2014). Monitoring Progress towards Universal Health Coverage at Country and Global Levels. PLoS Medicine, 11(9), 1-8.

Booth, A., \& Carroll, N. (2005). The health status of indigenous and non indigenous Australian. Australia: Australian National University.

Brown, W., \& Churchill, C. (2000). Insurance provision in low-income communities: Initial lessons from microinsurance experiments for the poor. Microenterprise best practices. Bethesda (MD): Development Alternatives Inc.

Bui, T. T. Q., \& Dao, H. C. (2016). The situation of the use of health insurance cards among informal employees and the factors district, Hanoi. Journal of Public Health, 6(42), 48-58.

Bundorf, M. K., \& Pauly, M. V. (2006). Is health insurance affordable for the uninsured?. Journal of Health economics, 25(4), 650-673.

Carrin, G. (2003). Community-based Health Insurance Schemes in Developing Countries: Facts, Problems and Perspectives. Geneva: Department of Health Financing and Stewardship WHO.

Carrin, G., Waelkens, M. P., \& Criel, B. (2005). Community-based health insurance in developing countries: a study of its contribution to the performance of health financing systems. Tropical Medicine \& International Health, 10(8), 799-811.

Chauhan, R. C., Manikandan, Purty, A. J., Samuel, A., \& Sin, Z. (2015). Determinants of health care seeking behavior among rural population of a coastal area in South India. International Journal of Scientific Reports, 1(2), 118-122.

Chen, M., Lund, F., Chatterjee, M., Thomas, S., Tulaphan, P., \& Tangworamongkon, C. (2015). Universal health care for informal workers: Lessons from India \& Thailand for overcoming barriers, addressing gender dimensions. Philippines: Asian Development Bank.

Chung, W. (2004). Income inequality and health: Evidence from Indonesia. Makalah Dipresentasikan dalam Seminar di Center for Labour Market Research. Australia: The University of Western.

Departemen Kesehatan. (2008). Kajian kondisi kerja pada usaha kecil menengah dan dampaknya pada kesehatan kerja. Jakarta: Dirjen Bina Kesehatan Masyarakat.

Dror, D. M., Hossain, S. S., Majumdar, A., Koehlmoos, T. L. P., John, D., \& Panda, P. K. (2016). What factors affect voluntary uptake of community-based health insurance schemes in low-and middle-income countries? a systematic review and meta-analysis. PloS one, 11(8), 1-31.

Edoh, D., \& Brenya, A. (2004). A community-based feasibility study of National Health Insurance Scheme in Ghana. African journal of health sciences, 9(1), 41-50.

Fang, P., Han, S., Zhao, L., Fang, Z., Zhang, Y., \& Zou, X. (2014). What limits the utilization of health services among the rural population in the Dabie Mountains-Evidence from Hubei province, China?. BMC Health Services Research, 14(1), 1-7.

Gerungan. (2004). Psikologi Sosial. Bandung: PT. Refika Aditama.

Ginneken, W. (2002). Social Security for the Informal Sector: A New Challenge for the Developing Countries. International Social Security Review, 52(1), 49-69.

Grossman, M. (1972). On the Concept of Health Capital and the Demand for Health. The Journal of Political Economy, 80(2), 223-255.

Handajani, A., Roosihermiatie, B., \& Maryani, H. (2010). Faktor-Faktor yang Berhubungan dengan Pola Kematian Pada Penyakit Degeneratif di Indonesia. Buletin Penelitian Sistem Kesehatan, 13(1), 42-53.

Harmon, C., \& Nolan, B. (2001). Health insurance and health service utilization in Ireland. Health Economics, $10(1), 135-145$. 
Holmes, R., \& Scott, L. (2016). Extending social insurance to informal workers - A gender analysis. London: ODI. Idris, H. (2016). Analisis Kebijakan Publik Jaminan Kesehatan Sektor Informal (Disertasi). Yogyakarta: Universitas Gadjah Mada.

International Labour Organization. (2013). Domestic workers across the world: Global and regional statistics and the extent of legal protection. Geneva: ILO.

Intiasari, A. D., Trisnantoro, L., \& Hendrartini, J. (2015). Potret Masyarakat Sektor Informal di Indonesia: Mengenal Determinan Probabilitas Keikutsertaan Jaminan Kesehatan Sebagai Upaya Perluasan Kepesertaan Pada Skema Non PBI Mandiri. Jurnal Kebijakan Kesehatan Indonesia, 4(4), 126-132.

Kementrian Kesehatan. (2019). Buku Pegangan Sosialisasi Jaminan Kesehatan Nasional (JKN) dalam Sistem Jaminan Sosial Nasional. Jakarta: Kementrian Kesehatan.

Kirigia, J. M., Sambo, L. G., Nganda, B., Mwabu, G. M., Chatora, R., \& Mwase, T. (2005). Determinants of health insurance ownership among South African women. BMC Health Service Research. Vol.5, No.17, pp.2-10.

Kirui, E. (2012). Determinants of Ownership of Health Insurance Among Employees Working in The Informal and Formal Sectors in Kenya Case Study Rift Valley Provinces (Tesis). Nairobi: University of Nairobi.

Kusi, A., Enemark, U., Hansen, K. S., \& Asante, F. A. (2015). Refusal to enrol in Ghana's National Health Insurance Scheme: is affordability the problem?. International journal for equity in health, 14(1), 1-14.

Kwadwo, W., Asenso-Okyere, Osei-Akoto, I., Anum, A., \& Appiah, E. N. (1997). Willingness to pay for health insurance in a developing economy: A pilot study of the informal sector of Ghana using contingent valuation. Health Policy and Planning, 42(3), 223-237.

Liu, T. C., \& Chen, C. S. (2002). An analysis of private health insurance purchasing decisions with national health insurance in Taiwan. Social Science \& Medicine, 55(5), 755-774.

Madya, S. D. O., \& Nurwahyuni, A. (2018). Determinan Sosial Ekonomi Kepemilikan Jaminan Kecelakaan Kerja pada Tenaga Kerja Informal di Indonesia: Analisis Data SUSENAS 2017. Jurnal Ekonomi Kesehatan Indonesia, 3(2), 76-83.

Marquis, M. S., \& Holmer, M. R. (1996). Alternative models of choice under uncertainty and demand for health insurance. The Review of Economics and Statistics, 77(3), 421-427.

Marten, R., McIntyre, D., Travassos, C., \& Shishkin, S. (2014). An Assessment of Progress towards Universal Health Coverage in Brazil, Russia, India, China, and South Africa (BRICS). Health Policy Report, 384(1), 64-71.

Medyati, N., Ridwan, A., Russeng, S., \& Stang. (2018). Karakteristik dan Prevalensi Resiko Penyakit Kardiovaskular Pada Tukang Masak Warung Makan di Wilayah Kerja Puskesmas Tamalanrea. Jurnal Kesehatan, 11(1), 30-38.

Mulenga, J. N., Bwalya, B. B., \& Gebremeskel, Y. (2017). Demographic and socio-economic determinants of women's health insurance coverage in Zambia. Epidemiology Biostatistics and Public Health, 14(1), 1-9.

Nosratnejad, S., Rashidian, A., Mehrara, M., Sari, A. A., Mahdavi, G., \& Moeini, M. (2014). Willingness To Pay for Social Health Insurance in Iran. Global Journal of Health Science, 6(5), 154-163.

Pandey, M. K. (2008). Association between marital status \& health: Examining the role of age \& gender. Munich Personal RePEc Archive Studi. 1-18.

Pitoyo, A. J. (2007). Dinamika Sektor Informal di Indonesia. Prospek, Perkembangan, dan Kedudukannya dalam Sistem Ekonomi Makro. Jurnal Populasi, 18(2), 129-146.

Rhine, S. L. W. (1998). The effect of employment status on private health insurance coverage: 1997 and 1987. Health Economics, 7(1), 63-79.

Schieber, G., Cashin, C., Saleh, K., \& Lavado, R. (2012). Health financing in Ghana. USA: World Bank Publications.

Schneider, P. (2004). Why should the poor insure? Theories of decision-making in the context of health insurance. Health Policy and Planning, 19(6), 349-355.

Suharto, E. (2009). Kemiskinan dan Perlindungan Sosial di Indonesia: Menggagas Model Jaminan Sosial Universal Bidang Kesehatan. Bandung: Penerbit Alfabeta.

Tana, L. (2015). Faktor Yang Berperan Pada Lama Rawat Inap Akibat Cedera Pada Kelompok Pekerja Usia Produktif di Indonesia. Buletin Penelitian Sistem Kesehatan, 19(1), 75-82.

Thabrany, H. (2008). Strategi Pendanaan Jaminan Kesehatan Indonesia dalam SJSN. Makalah Dipresentasikan dalam Diskusi RPJMN. Jakarta: BAPPENAS. (2011). Asuransi Kesehatan Nasional. Jakarta: Pamjaki.

Triyono, \& Soewartoyo. (2013). Kendala Kepesertaan Program Jaminan Sosial terhadap Pekerja di Sektor Informal: Studi Kasus di Kota Surabaya. Jurnal Hukum PRIORIS, 3(3), 26-41. 
Trujillo, A. J. (2003). Medical care use and selection in social health insurance with an equalization fund: evidence from Colombia. Health Economics, 12(3), 231-246.

Tubeuf, S., Jusot, F., Devaux, M., \& Sermet, C. (2008). Social heterogenity in self reported health status and measurement of inequalities in Health. Paris: Institut de recherche et documentation en économie de la santé.

WHO. (2015) Tracking Universal Health Coverage. First Global Monitoring Report. Geneva: WHO.

Wilson, C. M. \& Oswald, A. J. (2005). How does marriage affect physical and psychological health? A survey of the longitudinal Evidence. Germany: Forschungsinstitut zur Zukunft der Arbeit Institute for the Study of Labor.

Yamamura, E. (2009). Differences of the effects of social capital on health status among resident: Evidence from Modern Japan. MPRA Paper. 1-13. 